\title{
Characterization of a core fragment of the rhesus monkey TRIM5 $\alpha$ protein
}

\author{
Alak K Kar ${ }^{1,2}$, Youdong Mao ${ }^{1,2}$, Gregory Bird ${ }^{3}$, Loren Walensky ${ }^{3}$, Joseph Sodroski ${ }^{1,2,4^{*}}$
}

\begin{abstract}
Background: Like all tripartite motif (TRIM) proteins, the retroviral restriction factor TRIM5 $\alpha$ consists of RING, B-box 2 and coiled-coil domains, with a C-terminal B30.2(SPRY) domain. Although structures have been determined for some individual TRIM domains, the structure of an intact TRIM protein is unknown.

Results: Here, we express and characterize a protease-resistant 29-kD core fragment containing the B-box 2, coiled coil and adjacent linker (L2) region of TRIM5 $\alpha$. This BCCL2 protein formed dimers and higher-order oligomers in solution. Approximately $40 \%$ of the BCCL2 secondary structure consisted of alpha helices. Partial loss of alphahelical content and dissociation of dimers occurred at $42^{\circ} \mathrm{C}$, with the residual alpha helices remaining stable up to $80^{\circ} \mathrm{C}$.

Conclusions: These results indicate that the B-box 2, coiled-coil and linker 2 regions of TRIM5 $\alpha$ form a core dimerization motif that exhibits a high level of alpha-helical content.
\end{abstract}

\section{Background}

Soon after entry into the cells of certain mammalian species, some retroviruses encounter blocks mediated by the restriction factor TRIM5 $\alpha$. For example, human immunodeficiency virus (HIV-1), the causative agent of acquired immunodeficiency syndrome (AIDS), can infect human and chimpanzee cells, but is blocked in cells of Old World monkeys [1-5]. In contrast, simian immunodeficiency virus (SIVmac) infects Old World monkey cells but is restricted in the cells of most New World monkeys [3,6]. TRIM5 $\alpha$, a member of the tripartite motif (TRIM) family of proteins, mediates these early infection blocks [7-12]. Differences in TRIM5 $\alpha$ proteins among species account for the distinct patterns of retroviral restriction observed in mammalian lineages [5,7-12]. TRIM5 $\alpha$ has been shown to bind and promote the premature uncoating of incoming retroviral capsids [13-19].

Like all TRIM proteins, TRIM5 $\alpha$ contains RING, B-box 2 and coiled coil domains [20,21]. The $\alpha$ isoform of TRIM5, which is the only TRIM5 isoform that exhibits antiretroviral activity [7], also has a carboxy-

\footnotetext{
* Correspondence: Joseph_Sodroski@dfci.harvard.edu

'Department of Cancer Immunology and AIDS, Dana-Farber Cancer Institute, Harvard Medical School, Boston, MA, USA 02115

Full list of author information is available at the end of the article
}

terminal B30.2(SPRY) domain [20,21]. Mutagenic studies have shed light on the contribution of the TRIM5 $\alpha$ domains to antiretroviral activity. The RING domain, which exhibits E3 ubiquitin ligase activity, contributes to anti-HIV-1 potency, but is not absolutely required for a modest level of restriction ability [7,13,22-24]. The Bbox 2 domain is essential for higher-order associations among TRIM5 $\alpha$ dimers and contributes to the cooperative binding of TRIM5 $\alpha$ to the retroviral capsid $[14,16,25,26]$. The coiled coil and adjacent linker (L2) region are sufficient for dimerization of TRIM $5 \alpha$, which results in a higher avidity of TRIM $5 \alpha$-capsid binding [27-30]. The direct contact between TRIM5 $\alpha$ and the retroviral capsid is thought to be mediated by the B30.2 (SPRY) domain. Surface-exposed loops within the TRIM5 $\alpha$ B30.2(SPRY) domain exhibit pronounced variability and have been subject to positive selection during mammalian evolution [31-36]. Amino acid changes in these B30.2(SPRY) variable loops or in the viral capsid protein can alter capsid recognition and the specificity of retrovirus restriction [15,23,33,37-47].

Structural information on TRIM proteins is still limited. There are no published structures of a complete TRIM protein, even though some TRIM proteins (e.g., TRIM19 (promyelocytic leukemia (PML) protein), TRIM20 (pyrin), TRIM18 (MID1), TRIM21 (Rho/SSA)) 
and TRIM37 (MUL)) have been studied extensively due to their association with human diseases [48-54]. Poor expression levels and tendencies to aggregate into nuclear or cytoplasmic bodies have hampered efforts to obtain complete TRIM protein structures [20,21]. Nonetheless, structures of individual TRIM domains have been solved. The RING and B-box 2 structures of TRIM5 and other TRIM proteins have been solved by NMR [16,55-59]. Structures of the B30.2(SPRY) domains of TRIM21 as well as of several proteins not in the TRIM family have been obtained by $x$-ray crystallography [60-64]. No structural information on the coiledcoil domain of any TRIM protein is available. Such information would be very valuable, as the coiled coil presumably resides near the dimeric axis and provides a central scaffold for the positioning of the other TRIM domains. The TRIM coiled coil is predicted to be alpha helical [65-67], but lacks easily identifiable heptad repeat motifs that characterize some of the classical coiled coils for which structural information is available.

Recently, we have devised approaches that allow expression of sufficient quantities of TRIM5 $\alpha$ variants in baculovirus-infected cells for purification and biochemical characterization $[28,29]$. Substitution of the TRIM21 RING domain for that of rhesus monkey TRIM5 $\alpha$ resulted in a protein (TRIM5-21R) that was efficiently expressed and was purified. TRIM5-21R is a dimer and binds HIV-1 capsid-nucleocapsid (CA-NC) complexes assembled in vitro[28,29]. Binding of TRIM5-21R to HIV-1 CA-NC complexes depends upon the B30.2(SPRY) domain v1 variable region. Protease-resistant fragments of TRIM5-21R were characterized [28]. Here we describe the expression in E. coli, purification and characterization of one such fragment containing the B-box, coiled coil and linker 2 (L2) region of rhesus monkey TRIM5 $\alpha$.

\section{Methods \\ Plasmid construction and production of recombinant BCCL2 protein}

The recombinant bacterial construct expressing BCCL2 was prepared using the Champion pET Gateway vector with a kanamycin cassette(Invitrogen). Gateway recombination resulted in a gene that encodes an $\mathrm{N}$-terminal hexa-histidine tag, a spacer, and the BCCL2 protein. The predicted N-terminus of the resulting BCCL2 protein is HHHHHHGSGLVPRGSASMSDSEVNQEAKP EVKLSPEEGQK.... The recombinant vector was transformed into BL21(DE3)pLysS competent cells (Invitrogen). Five single colonies were picked and examined for expression. The colony exhibiting the highest level of BCCL2 expression was incubated in Luria Broth (LB) at $37^{\circ} \mathrm{C}$ till the OD reached 0.8 , at which time isopropylthiogalactoside (IPTG) was added to a final concentration of $1 \mathrm{mM}$; incubation was continued overnight at $18^{\circ} \mathrm{C}$. The cDNAs expressing the wild-type BCCL2 protein and B-box 2 mutants were cloned into pcDNA/ V5-GW/D-TOPO (Invitrogen) for expression in mammalian cells.

\section{Expression and purification of the BCCL2 proteins}

Single bacterial colonies were expanded and induced as described above. The cells were harvested by centrifugation at $4,000 \times g$ for 10 minutes, rinsed in phosphatebuffered saline, and resuspended at $2.5 \times 10^{7} \mathrm{cells} / \mathrm{ml}$ in Bacterial Protein Extraction Reagent (BPER) (Pierce Biotechnology) in the presence of $1 \mathrm{mM}$ dithiothreitol (DTT) and a cocktail of protease inhibitors comprising $10 \mathrm{mM}$ (amidinophenyl)-methanesulfonyl fluoride (APMSF), $10 \mathrm{mM} \mathrm{E}-64,10 \mathrm{mM}$ leupeptin, and $1 \mathrm{mM}$ pepstatin A (final concentrations). A sample was taken for analysis, and then the cell debris and nuclei were removed by centrifugation at $4,000 \times g$ for 10 minutes. The resulting cell supernatant was mixed with $\mathrm{Ni}^{+2}$ nitrilotriacetic acid (NTA) superflow resin (Qiagen) according to the manufacturer's protocol. Protein was eluted from the resin with $300 \mathrm{mM}$ imidazole. The eluted protein fraction was concentrated and was loaded on a Superdex 200 HR 10/30 size-exclusion chromatography (SEC) column (GE Healthcare). The column was equilibrated against PBS. Preparative SEC was run at $0.2 \mathrm{ml} / \mathrm{min}$ at $4^{\circ} \mathrm{C}$. A calibration curve for molecular size estimation was generated by loading gel-filtration markers (Biorad) comprising thyroglobulin $(667 \mathrm{kD})$, bovine gamma-globulin (158 kD), chicken ovalbumin (44 kD), equine myoglobin $(17 \mathrm{kD})$ and Vitamin $\mathrm{B}_{12}(1.35 \mathrm{kD})$ proteins onto this SEC column and eluting under similar conditions. The resulting fractions were analyzed by SDS-PAGE and those containing the BCCL2 protein were pooled and concentrated. For further purification, buffer was exchanged into $20 \mathrm{mM}$ Tris- $\mathrm{HCl} / 50 \mathrm{mM}$ $\mathrm{NaCl}, \mathrm{pH} 8$ by using a PD-10 column (Pharmacia). Anion-exchange chromatography was subsequently performed on a 5-ml Q-Sepharose Hi-Trap column (GE Healthcare) equilibrated with $20 \mathrm{mM}$ Tris- $\mathrm{HCl} / 50 \mathrm{mM}$ $\mathrm{NaCl}, \mathrm{pH}$ 8.0. Bound proteins were eluted by using a $\mathrm{NaCl}$ gradient (50 to $750 \mathrm{mM} \mathrm{NaCl}$ in $20 \mathrm{mM}$ Tris- $\mathrm{HCl}$, $\mathrm{pH}$ 8.0). The BCCL2 protein was eluted with $400 \mathrm{mM}$ $\mathrm{NaCl}$, and fractions containing the protein were pooled, dialyzed and concentrated by ultrafiltration with Centricon-10 devices (Amicon). The cocktail of protease inhibitors (at the concentrations referred to above) was added to the samples throughout each stage of the purification scheme. The BCCL2 protein was at least $95 \%$ pure, as determined by a Coomassie-stained gel.

\section{Elicitation of polyclonal antibodies in rabbits}

Polyclonal antibodies directed against the purified LLER protein were raised in rabbits by Open Biosystems 
(Huntsville, AL, USA). The rabbits were primed with $100 \mu \mathrm{g}$ of protein in Complete Freund's Adjuvant and boosted twice with $50 \mu \mathrm{g}$ protein in Incomplete Freund's Adjuvant.

\section{Western blotting}

Aliquots were collected at each step of BCCL2 purification and the associated proteins were resolved by sodium dodecyl sulfate-polyacrylamide gel electrophoresis (SDS-PAGE). The proteins were transferred to poly (vinylidene fluoride) (PVDF) Immobilon filters (Millipore) by a semidry blotting apparatus. Polyclonal rabbit antibody directed against the purified BCCL 2 protein was used as the primary antibody to detect the BCCL2 protein in Western blot experiments. Horseradish peroxidase (HRP)-conjugated goat anti-rabbit IgG was used as the secondary antibody. The Western blot was developed with the ECL chemiluminescence detection system (GE Healthcare) and the Kodak film processor system (Kodak).

\section{Analytical size-exclusion chromatography}

A sample of the $\mathrm{Ni}^{+2}$-affinity-purified BCCL 2 protein was fractionated by size exclusion on a Superdex 200 $(10 / 30)$ column calibrated with molecular-weight markers. The column was equilibrated in PBS at a flow rate of $0.4 \mathrm{ml} / \mathrm{min}$, and the absorbance of the eluted protein was recorded at $280 \mathrm{~nm}$. The column was mounted on a high-performance liquid chromatography system (Varian Star). Fractions were collected every minute, and a sample from each fraction was analyzed by SDS-PAGE.

\section{Size-Exclusion Chromatography-Light Scattering (SEC-LS)} The molecular masses of full-length proteins were determined by Ewa Folta-Stogniew using SEC-LS in the HHMI Biopolymer Facility and W. M. Keck Foundation Biotechnology Resource Laboratory at Yale University. Briefly, a sample containing approximately $300 \mu \mathrm{g}$ of LLER protein was filtered through a $0.22-\mu \mathrm{m}$ Durapore membrane (Millipore) and applied to a Superose $6 \mathrm{HR}$ 10/30 column coupled with an in-line Dawn EOS laser light-scattering apparatus (Wyatt Technology Corporation), refractometer (Wyatt Technology), and UV detector (Waters Corporation). The average molecular mass of the elution peak was calculated using ASTRA software.

\section{Mass spectrometry}

Matrix-assisted laser desorption ionization-time of flight (MALDI-TOF) mass spectrometry of the LLER protein was performed at the Molecular Biology Core Facility at Dana-Farber Cancer Institute (Boston, MA), using a sinapinic acid matrix.

\section{Dynamic Light Scattering}

Measurements were carried out using a temperaturecontrolled Zetasizer Nano-S (Malvern) at $20^{\circ} \mathrm{C}$. A protein solution $(0.5 \mathrm{mg} / \mathrm{ml})$ was filtered through a $0.2-\mu \mathrm{m}$ membrane into a $20^{\circ} \mathrm{C}$ pre-warmed light-scattering cuvette and measurements were carried out according to the manufacturer's instructions.

\section{Crosslinking of the purified BCCL2 protein}

The purified LLER protein $(1 \mathrm{mg} / \mathrm{ml})$ was incubated with various concentrations (final concentrations of 0 , $0.25,0.5,1$ and $1.0 \mathrm{mM}$ ) of glutaraldehyde (Sigma) at room temperature for 8 minutes, after which $0.1 \mathrm{M}$ Tris- $\mathrm{HCl}, \mathrm{pH} 7.5$ was added to quench the reaction. The crosslinked proteins were boiled in SDS-denaturing buffer and subjected to SDS-PAGE (4-12\% acrylamide) and Coomassie Blue staining.

Transiently transfected 293 T cells expressing wildtype rhesus monkey BCCL2 and the corresponding B-box 2 mutants were washed in phosphate-buffered saline (PBS) and lysed in NP40 lysis buffer (0.5\% Nonidet P40 (NP40), $1 \times$ protease inhibitor (complete EDTAfree, Roche Diagnostics) in PBS) for 45 minutes at $4{ }^{\circ} \mathrm{C}$. Lysates were centrifuged at $14,000 \times g$ for 15 minutes at $4^{\circ} \mathrm{C}$. Lysates were crosslinked with varying concentrations (up to $2 \mathrm{mM}$ ) of glutaraldehyde for 8 minutes at room temperature and centrifuged briefly in a table-top centrifuge. The reaction mix was quenched with $0.1 \mathrm{M}$ Tris- $\mathrm{HCl}, \mathrm{pH} 7.5$, briefly centrifuged and analyzed by Western blotting as described above.

\section{Native gel electrophoresis}

Electrophoresis was performed using the Novex Polyacrylamide Gel Electrophoresis System (Invitrogen). Protein samples were mixed with native gel running buffer (0.1 M Tris-HCI ( $\mathrm{pH} 8.8$ ), 20\% glycerol, and $0.0025 \%$ bromophenol blue) to a final concentration of $0.5 \mathrm{mg} /$ $\mathrm{ml}$. Thirty microliters of each sample was loaded onto a 4-16\% gradient polyacrylamide gel and run at $150 \mathrm{~V}$ in Tris-glycine buffer $(0.192 \mathrm{M}$ acetate and $0.25 \mathrm{M}$ Tris at $\mathrm{pH}$ 8.3). After the dye front migrated to the bottom of the gel, the gel was developed using Coomassie Blue staining. The unstained NativeMark protein standard (Invitrogen) was used for markers.

\section{Electron Microscopy}

For negative staining, the purified LLER protein was directly applied to carbon-coated grids after glow discharge. These were negatively stained with $1 \%(\mathrm{w} / \mathrm{v})$ uranyl formate and observed in a Tecnai G2 Spirit BioTWIN (FEI Company) electron microscope operated at $100 \mathrm{kV}$. Micrographs were recorded at a magnification of 100,000 $\mathrm{x}$ and pictures taken under low-dose conditions. 
For cryo-electron microscopic analysis, $3 \mu \mathrm{l}$ of the protein solution was applied to a Quantifoil grid, blotted by filter paper for 2 seconds and immediately plunged into liquid ethane; the whole process was performed with an FEI Vitrobot. The prepared cryo-grids then were subjected to imaging in a Tecnai F20 field-emission gun electron microscope equipped with a Gatan CT3500 cryo-transfer holder that was cooled down to $-180^{\circ} \mathrm{C}$ by liquid nitrogen. Micrographs were recorded in bright-field mode at a magnification of 150,000 $\times$ and at a defocus of $\sim 3-5 \mu \mathrm{m}$ by a $4 \mathrm{k} \times 4 \mathrm{k}$ Gatan CCD camera, with a total dose no greater than 100 electrons per $\mathrm{nm}^{2}$.

\section{Circular dichroism (CD) spectroscopy}

Samples for circular dichroism (CD) spectroscopy were buffer-exchanged into PBS. The CD spectrum was measured with an Aviv 410 CD spectrometer (Aviv Biomedical), using a quartz cuvette with a path length of $0.1 \mathrm{~cm}$. Measurements were obtained in 0.5-nm intervals from 195 to $245 \mathrm{~nm}$, a 1-nm bandwidth, and a 0.5$\mathrm{s}$ measurement time at each wavelength. Instrument units were converted to mean residue molar ellipticity according to the formula: $\theta=$ millidegree/molar concentration/number of amino acids. The percentage of secondary structure was calculated using the following formula: $\%$ helicity $=100 \times \theta_{222}($ observed $) / \theta_{222}(\max )$, where $\theta_{222}(\max )=-40,000 \times[1-(2.5 /$ number of amino acid residues)].

\section{Results}

\section{Expression and purification of a core fragment of TRIM5 $\alpha_{\text {rh }}$}

TRIM5-21R is a chimeric protein containing the RING domain of TRIM21 and the B-box 2, coiled coil, linker 2 and B30.2(SPRY) domain of TRIM $5 \alpha_{\mathrm{rh}}[28,29]$. TRIM5-21R, like many TRIM proteins [20,21], is prone to aggregation at high concentrations. To identify constructs that might be better behaved, we characterized TRIM5-21R fragments that were relatively resistant to trypsin and chymotrypsin digestion [28]. Proteins corresponding to these protease-resistant fragments were expressed in E. coli. Among the several constructs tested, the BCCL2 protein was soluble and able to be purified in adequate amounts following affinity purification (Table 1). The BCCL2 protein consists of an Nterminal $\mathrm{His}_{6}$ tag and a vector-derived spacer fused to the B-box 2 domain, the coiled-coil domain and the linker 2 (L2) region of TRIM $5 \alpha_{\mathrm{rh}}\left({ }^{83}\right.$ EVKLSPEE... MEFRLTDA $\left.{ }^{296}\right)$; the predicted molecular weight of the BCCL2 protein is $29.026 \mathrm{kD}$. Although the BCCL2 protein lacks a B30.2(SPRY) domain, which is needed for HIV-1 capsid binding and virus restriction [7,19,28,29], it retains the other TRIM $5 \alpha$ domains required for
Table 1 Expression and solubility of rhesus monkey TRIM5 $\alpha$ variants in E. coli

\begin{tabular}{lcc}
\hline Construct $^{\mathbf{a}}$ & Soluble $^{\mathbf{b}}$ & Inclusion $^{\text {Body }^{\mathbf{b}}}$ \\
\hline Full-length TRIM5 $\alpha$ & + & + \\
RBCC & - & +++++ \\
RBCCL2 & $+/-$ & ++ \\
RING-BCCL2 & - & + \\
BCC & - & +++ \\
BCCL2 & +++ & ++++
\end{tabular}

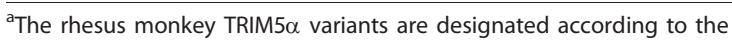
domains included in the protein: $\mathrm{R}=\mathrm{RING}$ domain; $\mathrm{B}=\mathrm{B}$-box 2 domain; $\mathrm{CC}=$ coiled-coil domain; L2 = linker 2 region. All of the TRIM5 $\alpha$ constructs were expressed in BL21(DE3)pLysS E. coli using the Champion pET Gateway vector, which adds an $\mathrm{N}$-terminal hexa-histidine tag and a spacer. The inserted fragment of the RBCCL2 protein corresponds to the TRIM $5 \alpha_{r h}$ sequences ${ }^{1}$ MASGILL...MEFRLTDA ${ }^{296}$. The inserted fragment of the RING-BCCL2 protein corresponds to the TRIM $5 \alpha_{\text {rh }}$ sequences ${ }^{15}$ CPICLE...MEFRLTDA ${ }^{296}$

${ }^{\mathrm{b}}$ The amount of protein found in the soluble and insoluble (inclusion body) fractions is indicated, with increased levels designated by increasing numbers of plus signs.

inhibition of HIV-1 infection. The BCCL2 protein with an $\mathrm{N}$-terminal $\mathrm{His}_{6}$ tag was expressed in the BL21(DE3) strain of E. coli under the control of the T7 promoter. Different temperatures, times/duration of induction, and IPTG concentrations were studied to identify conditions under which BCCL2 protein expression was maximal, while maintaining adequate solubility. Optimal conditions involved treatment with $1 \mathrm{mM}$ IPTG at an optical density of the culture of 0.8 and an overnight induction at $18^{\circ} \mathrm{C}$. Although a significant portion (approximately $60-70 \%)$ of the BCCL2 protein remained in the insoluble pellet, soluble BCCL2 protein (approximately $0.1 \mathrm{mg} /$ liter of E.coli) was obtained and was affinity purified using Ni-NTA beads and elution with $250 \mathrm{mM}$ imidazole (Figure 1A).

The affinity-purified BCCL2 protein was analyzed by gel-filtration chromatography (Figure 1B). The BCCL2 protein migrated in overlapping broad peaks at positions corresponding to molecular weights of approximately 50 - $400 \mathrm{kD}$. The BCCL2 protein was further purified by anion-exchange chromatography, where it eluted in a single peak (Figure 1C). The purified protein fractions (fractions 24 to 27 ) were pooled, concentrated and stored at $4^{\circ} \mathrm{C}$ (short-term) or at $-20^{\circ} \mathrm{C}$ at concentrations less than $0.5 \mathrm{mg} / \mathrm{ml}$ (long-term).

\section{Effects of B-box 2 changes on BCCL2 expression and oligomerization}

The self-association of TRIM5 $\alpha$ dimers in higher-order complexes is dependent upon specific charged and hydrophobic residues on the surface of the B-box 2 domain $[16,26]$. To investigate whether TRIM5 $\alpha$ selfassociation might contribute to the behavior of the BCCL2 protein, we altered B-box 2 residues previously shown to contribute to higher-order association $[16,26]$ 


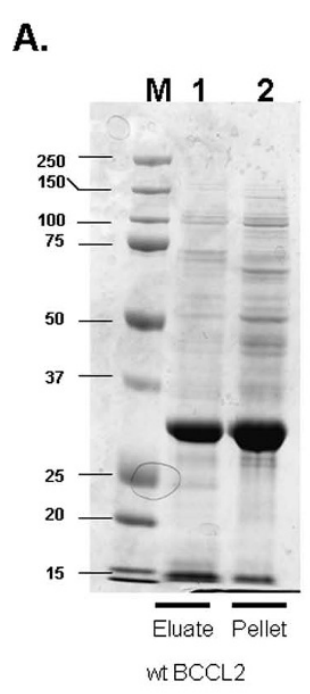

B.

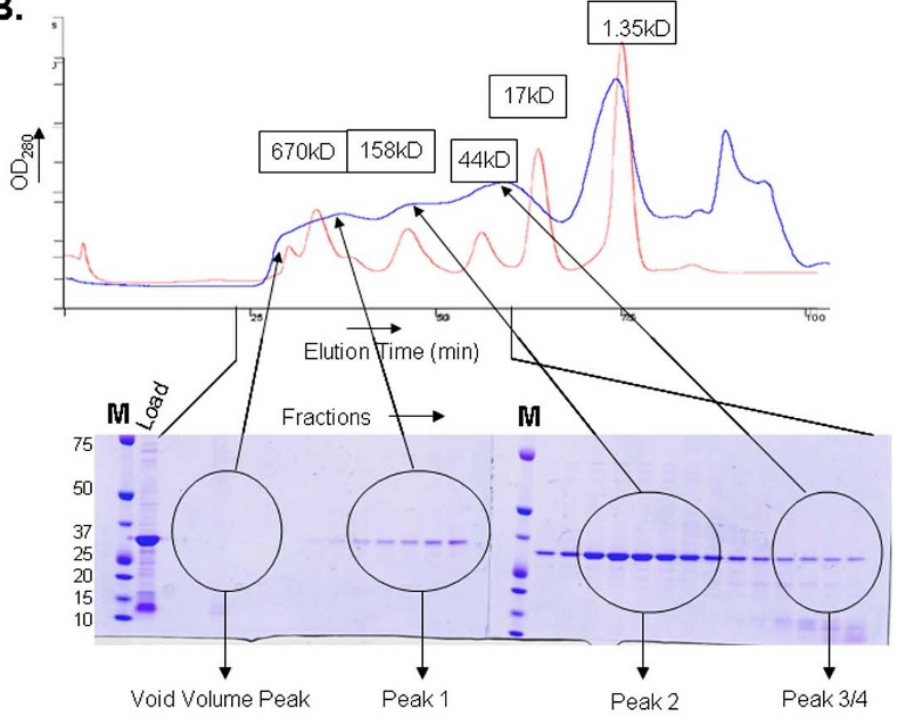

C.

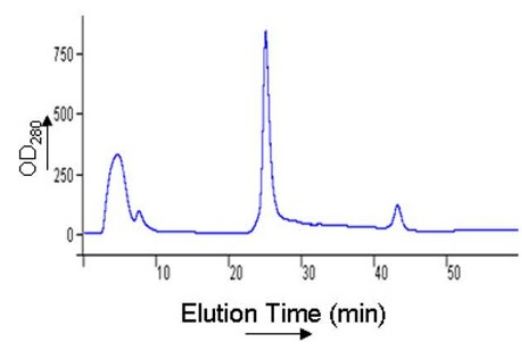

Fractions 20212223242526272829303132

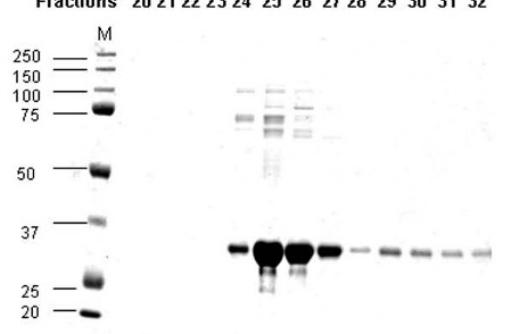

Figure 1 Purification of the BCCL2 protein expressed in bacteria. A. Bacterial cells expressing the BCCL2 protein were lysed and the homogenates subjected to purification approaches. In lane 1, the soluble BCCL2 protein was purified by $\mathrm{Ni}^{+2}-\mathrm{NTA}^{-}$metal-affinity chromatography. Lane 2 shows the insoluble pellet obtained after lysis of the bacteria with lysis buffer. The proteins in each sample were resolved by SDS-PAGE and Coomassie Blue staining. B. The affinity-purified BCCL2 protein was loaded onto a gel-filtration column and eluted at a flow rate of $0.3 \mathrm{ml} / \mathrm{min}$. The $\mathrm{OD}_{280}$ of the eluted protein is plotted (blue line). The profile of the globular protein standards (thyroglobulin (670 kD), bovine gamma-globulin (158 kD), chicken ovalbumin (44 kD), equine myoglobin (17 kD) and vitamin B12 (1.35 kD) is shown in red. Fractions from the gel-filtration column were separated on a 12\% SDS-polyacrylamide gel, which was stained with Coomassie Blue. An aliquot of the BCCL2 protein sample loaded on the gel-filtration column was analyzed (Load), along with the molecular-weight markers (M). C. The affinitypurified BCCL2 protein was loaded onto a Hi-trap Q anion-exchange column and eluted at a flow rate of $0.5 \mathrm{ml} / \mathrm{min}$ (left panel). The fractions from the column were separated on a 12\% SDS-polyacrylamide gel, which was stained with Coomassie Blue (right panel).

(Table 2). Several-fold increases in the amount of the BCCL2 protein that could be solubilized resulted from the changes in the B-box 2 domain (Figure 2). The expression level of soluble B-box mutant proteins such

Table 2 B-box 2 variants of the BCCL2 protein

\begin{tabular}{lc}
\hline BCCL2 Variant & B-box 2 changes \\
\hline wild-type $(w t)$ & E120R, R121E \\
ER & W117E, L118S \\
WL & W117E, E120R, R121E \\
WER & L105E, L106E, W117E, L118S \\
LLWL & L105E, L106E, E120R, R121E \\
\hline LLER
\end{tabular}

as LLER was approximately $1-2 \mathrm{mg} /$ liter of E.coli. The B-box 2 mutants (LLWL and LLER) with multiple surface changes eluted as two major peaks on a gelfiltration column, in contrast to the broad peak observed for the wild-type BCCL2 protein (Figure 3). The LLER protein demonstrated the clearest separation into two peaks of approximately 170 and $400 \mathrm{kD}$.

\section{Effect of zinc on LLER expression and oligomerization}

Because the B-box 2 domain of the BCCL2 protein binds two zinc ions [16], we investigated the effect of zinc supplementation and DTT treatment on the expression and oligomerization of the LLER variant. No augmentation of LLER expression resulted from 


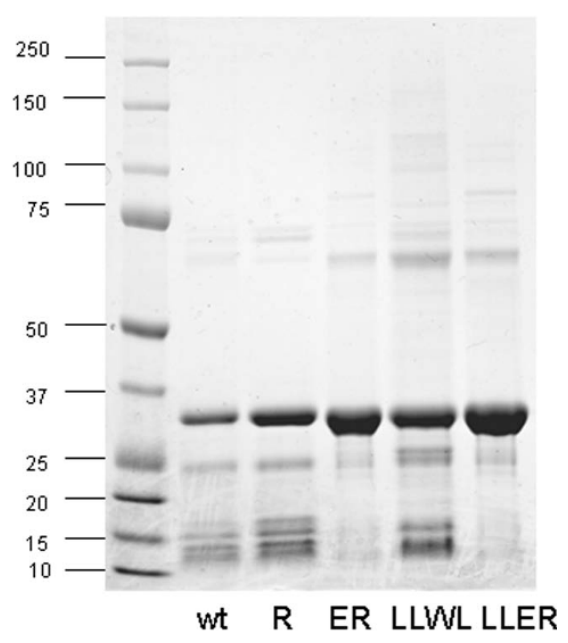

Figure 2 Effect of B-box 2 changes on BCCL2 expression and solubility. The wild-type (wt) BCCL2 protein and the indicated Bbox 2 mutants were expressed in E. coli. The bacteria were lysed and the lysates centrifuged at $4000 \times \mathrm{g}$ for 10 minutes. The supernatants were loaded onto a $\mathrm{Ni}^{+2}$-NTA affinity column; the proteins eluted with $300 \mathrm{mM}$ imidazole were analyzed by SDS-PAGE and Coomassie Blue staining. supplementation of growth medium with $25-100 \mathrm{mM}$ $\mathrm{ZnCl}_{2}$; in fact, LLER expression was diminished at the highest $\mathrm{ZnCl}_{2}$ concentration tested (data not shown). The addition of $\mathrm{ZnCl}_{2}$ or DTT did not significantly affect the elution profile of the LLER protein on gelfiltration chromatography (Figure 4 and data not shown).

\section{Dynamic light scattering analysis of the oligomeric state of the LLER protein}

The oligomeric state of the LLER protein, purified by nickel-affinity and anion-exchange chromatography, was investigated by size-exclusion chromatography-light scattering (SEC-LS). SEC-LS can estimate molecular mass independently of the Stokes radius of the protein and without reference to a curve based on protein standards. Molecular mass determination by SEC-LS depends only upon the light-scattering and refractive indices, which are measured by detectors situated downstream of the size-exclusion column. The LLER protein eluted in two peaks, the first ranging from $140-160 \mathrm{kD}$, the second from 57-61 kD (Figure 5A). A size analysis by Astra (Figure 5B) calculated a hydrodynamic radius of approximately $4.8 \mathrm{~nm}$. The molecular weight of the protein in Peak 2 is consistent with that expected for a

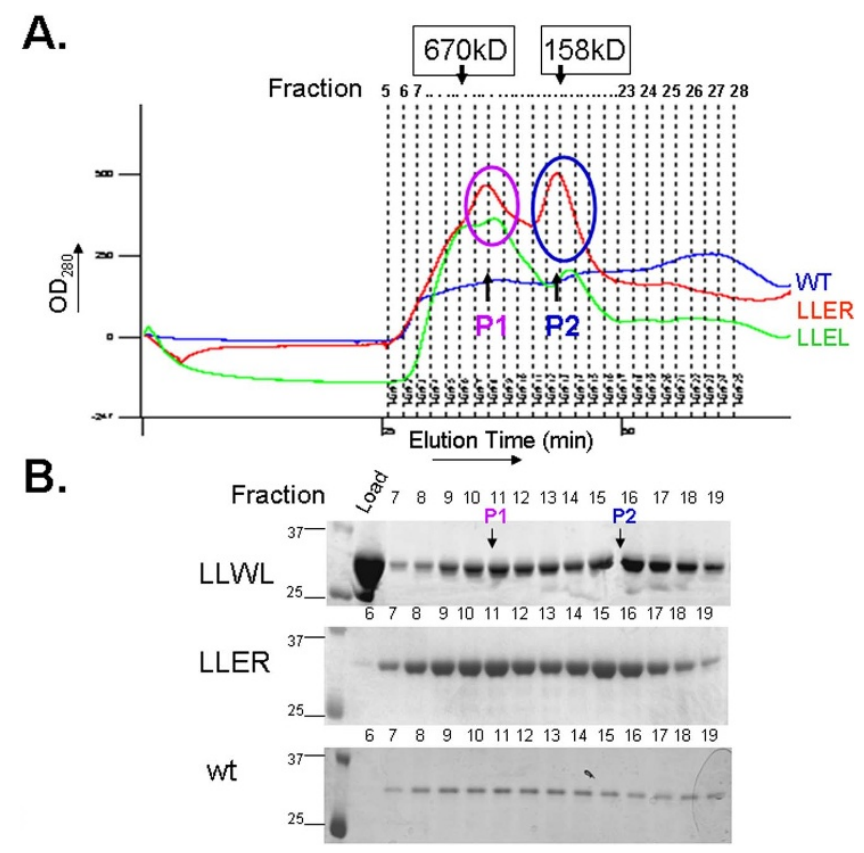

Figure 3 Comparison of the size-exclusion chromatography profiles of the wild-type and mutant BCCL2 proteins. A. Purified wild-type (wt) and mutant BCCL2 proteins were loaded onto a gel-filtration column and eluted at a flow rate of $0.3 \mathrm{ml} / \mathrm{min}$. The protein peaks 1 (P1) and 2 (P2) are indicated. The positions at which the globular proteins standards thyroglobulin (670 kD) and bovine gamma-globulin (158 kD) were eluted in a parallel run are indicated. B. Fractions from the gel-filtration column were separated on a 12\% SDS-polyacrylamide gel, which was stained with Coomassie Blue (bottom panel). The 25- and 37-kD molecular weight markers (M) are shown in the left-most lanes. An aliquot of the LLWL protein loaded on the gel-filtration column was also analyzed (Load). The positions of peaks P1 and P2 are noted. 


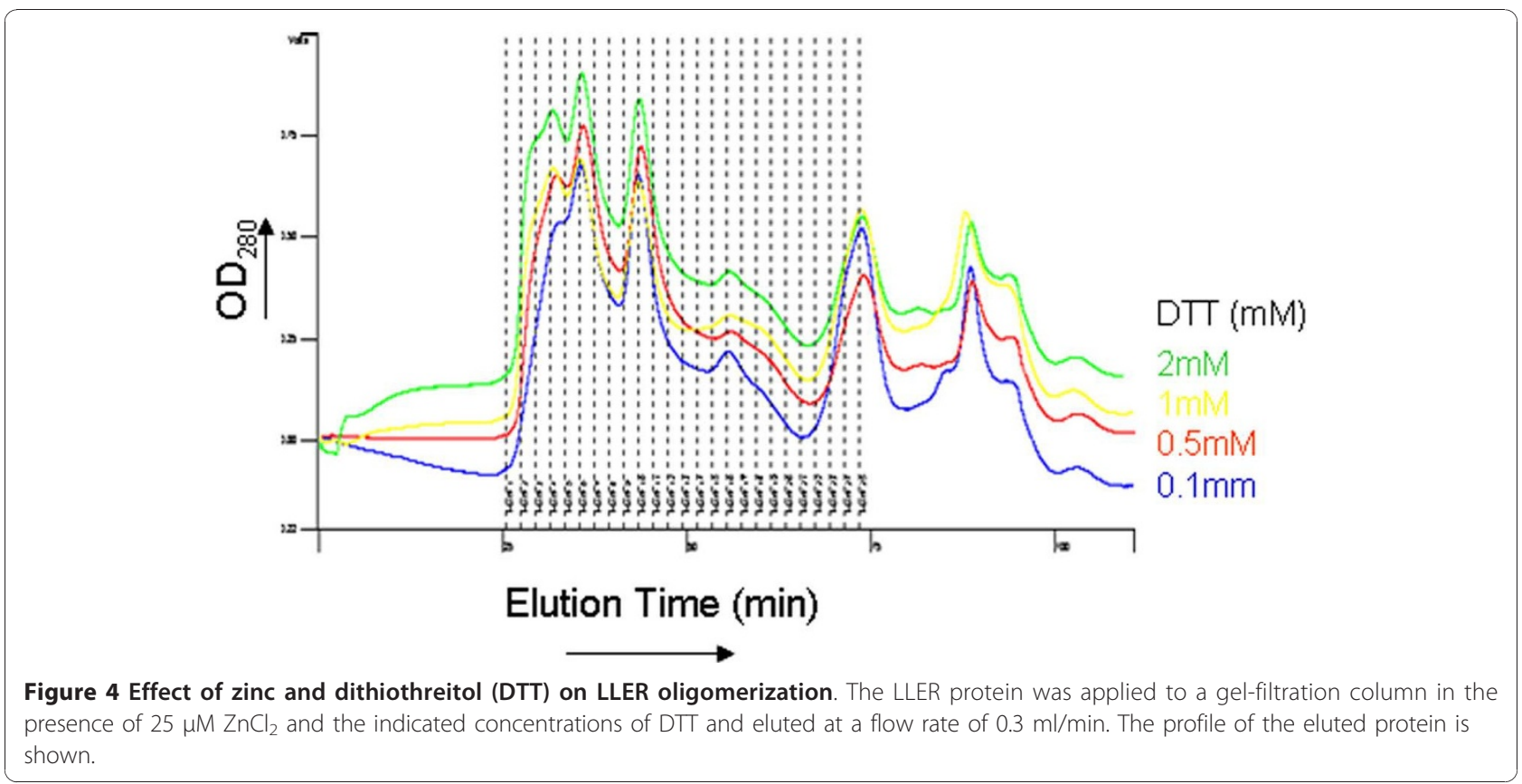

dimer, whereas the protein in Peak 1 apparently represents a higher-order oligomer.

We conducted additional dynamic light-scattering analysis of the two purified LLER protein fractions from size-exclusion chromatography (Figure 6). The protein in Peak 1 exhibited a diameter of $11.6 \mathrm{~nm}$ and a polydispersity of $22 \%$, and the protein in Peak 2 exhibited a diameter of $8.6 \mathrm{~nm}$ and a polydispersity of $45 \%$.

\section{Crosslinking analysis of the LLER protein}

The oligomeric state of the LLER protein was examined by chemical crosslinking with glutaraldehyde, followed by analysis on an SDS-polyacrylamide gel. The major crosslinked form of the protein migrated around $60 \mathrm{kD}$, suggestive of a dimer (Figure 7A). Smaller quantities of higher-order, approximately 150-kD forms were observed after crosslinking.

Next, the LLER protein from gel-filtration fractions (Peaks 1 and 2) were crosslinked with glutaraldehyde and analyzed. The LLER protein in Peak 2 mainly crosslinked into dimers. By contrast, the protein in Peak 1 formed fewer dimers and crosslinked primarily into higher-molecular-weight species (Figure 7B).

Because crosslinked TRIM5 protein can migrate aberrantly on SDS-polyacrylamide gels [27-29,68], the LLER protein crosslinked with glutaraldehyde was analyzed by mass spectrometry. Most of the untreated LLER protein exhibited a mass consistent with a monomer $(28,720 \mathrm{Da})$, with a small amount of dimer $(57,700 \mathrm{Da})$
(Figure 7C). The LLER protein crosslinked with glutaraldehyde demonstrated approximately equivalent amounts of monomer $(31,094 \mathrm{Da})$ and dimer $(61,716 \mathrm{Da})$ (Figure 7D). These results support the conclusion that the LLER protein is mainly dimeric, with some higher-order forms. Approximately half of the LLER protein migrated on native gels at a size consistent with a dimer, with most of the remainder of the protein migrating as a monomer; a small fraction of the protein migrated as a higher-order oligomer (data not shown).

The oligomeric state of the wild-type BCCL2 protein was compared with that of the B-box 2 mutants. For this purposes, the proteins were expressed transiently in 293 FT human kidney cells. Compared with the wildtype BCCL2 protein, the B-box 2 mutants were expressed comparably (Figure 8A) and exhibited a similar pattern upon crosslinking (Figure 8B). Thus, all of the B-box 2 mutants retain the ability to dimerize.

\section{Circular dichroism (CD) Spectrometry}

The CD spectrum of the LLER protein was determined at different temperatures (Figure 9A). The spectrum is characterized by a large negative change of ellipticity at 222 $\mathrm{nm}$ and is typical of that expected for a structured, predominantly alpha-helical, protein [69]. A quantitative analysis of the spectra obtained at different temperatures suggested that an extended alpha-helical conformation exists over a wide range of temperatures. The stability of the protein was examined by monitoring the effect of 

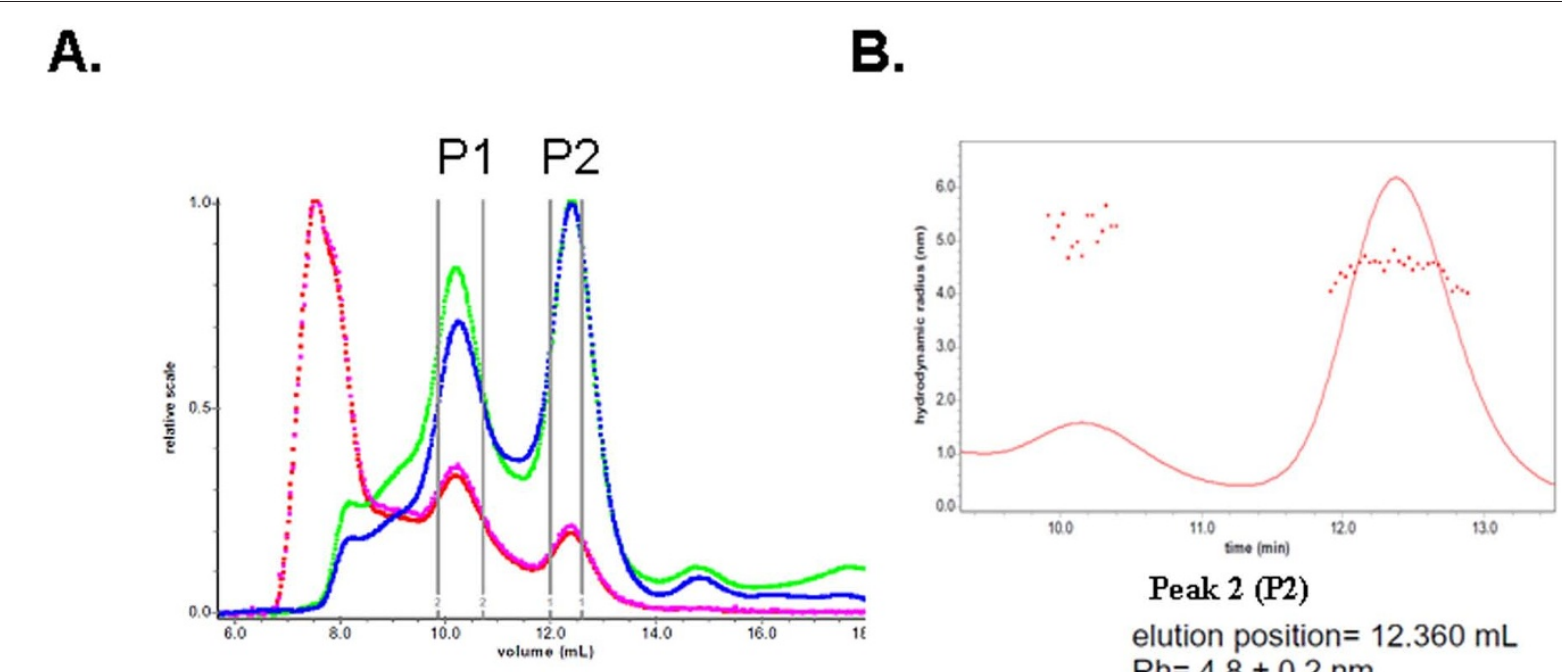

Peak 2 (P2)

elution position $=12.360 \mathrm{~mL}$ $\mathrm{Rh}=4.8 \pm 0.2 \mathrm{~nm}$ $\mathrm{Dt}=(5.08 \pm 0.20) \mathrm{e}-7 \mathrm{~cm}^{2} / \mathrm{sec}$ $\mathrm{Mw}=(5.918 \pm 0.006) \mathrm{e}+4 \mathrm{~g} / \mathrm{mol}$

Results of SEC-LS/RI/UV analysis from ASTRA

\begin{tabular}{|c|c|c|c|c|}
\hline Protein & $\begin{array}{l}\text { PEAK } \\
\text { Elution at } \\
\text { UV trace } \\
\text { (ml) }\end{array}$ & $\begin{array}{l}\text { MW } \\
\text { calculated by } \\
\text { ASTRA } \\
\text { (Average MW for } \\
\text { the major peak) }\end{array}$ & $\begin{array}{c}\text { MW } \\
\text { calculated by } \\
\text { ASTRA } \\
\text { (Range of MW } \\
\text { observed) }\end{array}$ & $\begin{array}{c}\text { Predicted MW } \\
\text { for monomer } \\
(\mathrm{kDa})\end{array}$ \\
\hline \multirow{2}{*}{ Peak 1} & 10.18 & $145 \mathrm{kDa}$ & $140-160 \mathrm{kDa}$ & \multirow{3}{*}{29.02} \\
\hline & 12.38 & $61 \mathrm{kDa}$ & $59-65 \mathrm{kDa}$ & \\
\hline Peak 2 & 12.37 & $59 \mathrm{kDa}$ & $57-61 \mathrm{kDa}$ & \\
\hline
\end{tabular}

Figure 5 Size-exclusion chromatography-light scattering (SEC-LS) analysis of the LLER protein. A. Approximately $300 \mu \mathrm{g}$ of the purified LLER protein was applied to a Superose 6 HR 10/30 column coupled with an in-line Dawn EOS laser light-scattering apparatus, refractometer and UV detector. The dashed red line represents the light-scattering signal at $90^{\circ}$. The green trace represents the refractive index. The blue trace represents the UV absorption at $280 \mathrm{~nm}$. B. The solid red line indicates the refractometer trace of Peak 1 (P1) and Peak 2 (P2). The "dots" represent the weight-average molecular mass for each slice, measured every second. The results of the analysis performed on the protein in Peak 2 (P2) are shown beneath the figure. The table summarizes the analyses of Peaks 1 and 2.

temperature on the far UV CD spectrum at $222 \mathrm{~nm}$ (Figure 9B). The LLER protein exhibited a biphasic loss of alpha-helical content, with one transition at $42^{\circ} \mathrm{C}$ and another near $80^{\circ} \mathrm{C}$. The $42^{\circ} \mathrm{C}$ transition occurs concomitantly with a dramatic decrease in the dimerization of the protein, as judged by crosslinking analysis (Figure 9C).

\section{Protease resistance of the $\mathrm{BCCL} 2$ protein}

The protease resistance of the LLER protein was compared with that of the TRIM $5 \alpha-21 R$ protein by incubating the proteins with trypsin. At incubation times where the TRIM5 $\alpha-21 R$ was substantially degraded to smaller fragments by trypsin, the LLER protein was retained in significant amounts (Figure 10). A major portion of the LLER protein is resistant to digestion, suggesting that these fractions are either compactly folded or represent higher-order oligomers that are resistant to trypsin digestion.

\section{Electron microscopy of the LLER protein}

The purified LLER protein was examined by negative staining under a transmission electron microscope. 


\section{A. Peak P1}

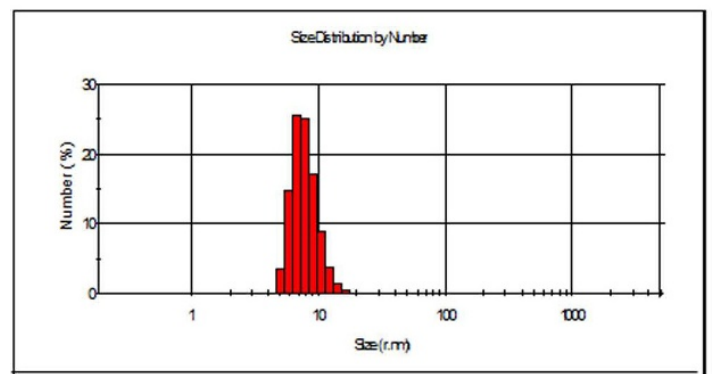

Peak Diam(nm) \%inten Width \%Pd

$\begin{array}{lllll}\text { Pla } & 11.56 & 95.8 & 3.30 & 0.217\end{array}$

$\begin{array}{llrr}\text { Plb } & 2290 & 4.4 & 417.6\end{array}$
B. Peak P2

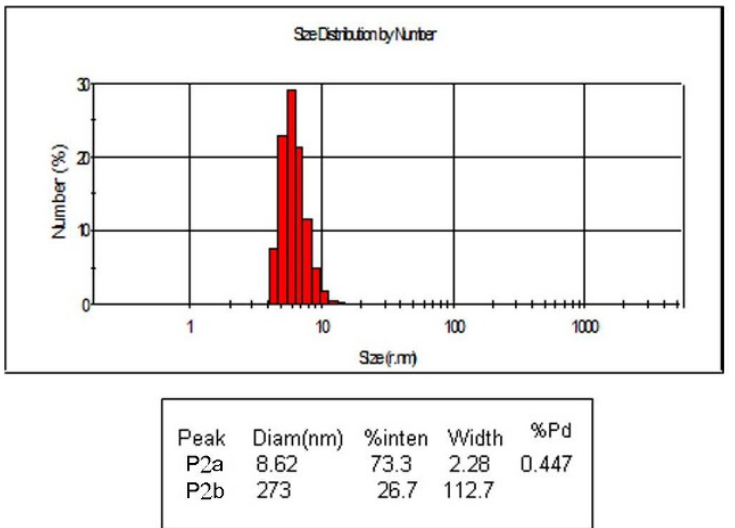

Figure 6 Dynamic light scattering analysis of the LLER protein. The polydispersity (\%Pd) and size (mean and mode, in $\mathrm{nm}$ ) of the purified LLER protein were estimated by dynamic light scattering. A $12-\mu \mathrm{l}$ sample of a $500 \mu \mathrm{g} / \mathrm{ml}$ solution of the LLER protein in peak 1 (A) and peak 2 (B) were analyzed by a temperature-controlled Zetasizer Nano-S dynamic light-scattering instrument at $20^{\circ} \mathrm{C}$.

A.

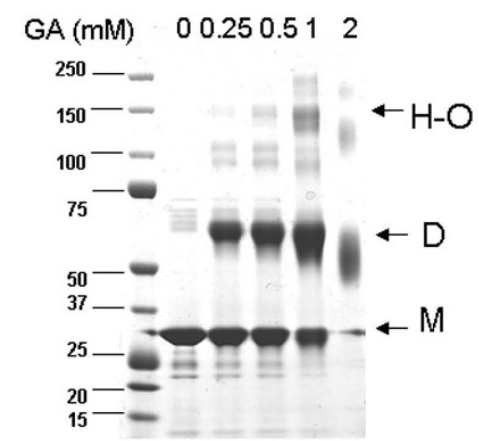

C.

28720.08

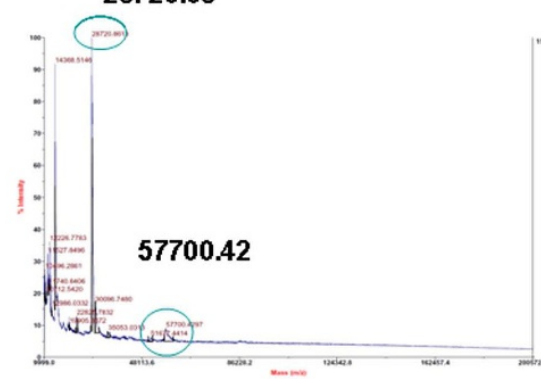

B.

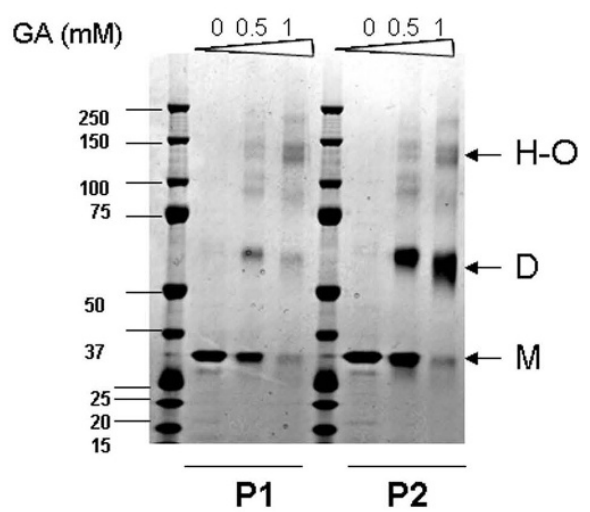

D.

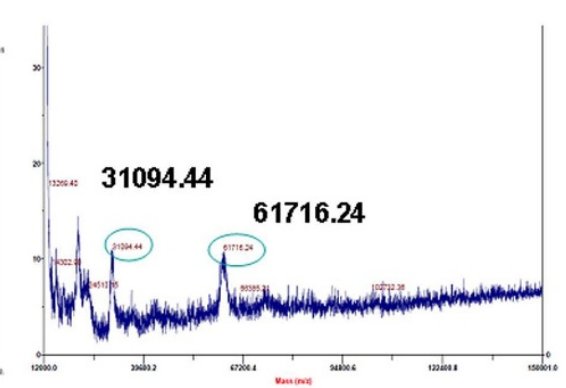

Figure 7 Crosslinking analysis of the LLER protein. A. The LLER protein, purified by nickel-affinity and anion-exchange chromatography, was incubated with the indicated concentrations (in $\mathrm{mM}$ ) of glutaraldehyde (GA). The protein was then boiled in Laemmli buffer and analyzed on a 4-12\% SDS-polyacrylamide gel. The arrow indicates the positions of the monomers (M), dimers (D) and higher-order oligomers (H-O). B. The peak 1 (P1) and peak 2 (P2) fractions of the LLER protein were purified by gel-filtration chromatography and separately crosslinked by incubation with the indicated concentrations of glutaraldehyde (GA). The proteins were then analyzed on a 4-12\% SDS-polyacrylamide gel. C, D. The LLER protein was either untreated (C) or crosslinked with glutaraldehyde (D) prior to MALDI-TOF analysis. The molecular mass estimations in daltons for the single mass ionization peaks are shown. 


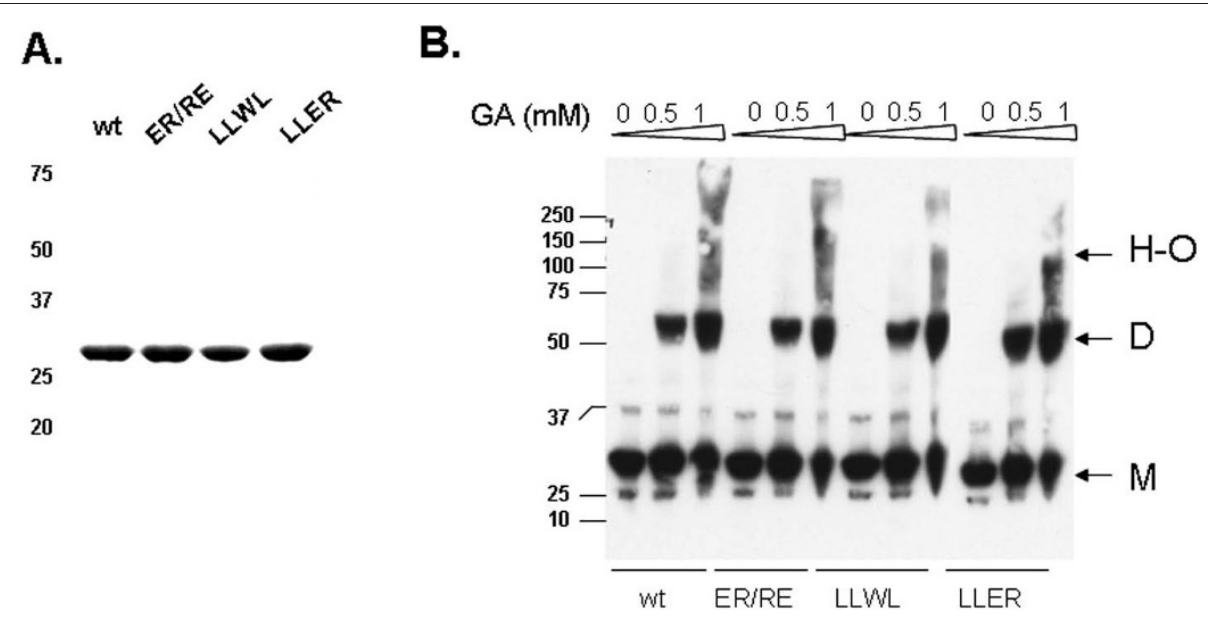

Figure 8 Oligomerization state of BCCL2 variants in mammalian cells. A. Lysates from 293 T cells expressing the wild-type (wt) and mutant BCCL2 proteins with V5 epitope tags were analyzed by $12 \%$ SDS-PAGE and Western blotted with an HRP-conjugated anti-V5 antibody. B. Lysates from 293 T cells expressing the wild-type (wt) and mutant BCCL2 proteins were treated with the indicated concentrations of glutaraldehyde and then boiled in Laemmli buffer and analyzed by SDS-PAGE and Western blotting, as described above. The positions of the molecular-weight markers in $\mathrm{kD}$ are shown. The arrows indicate the positions of monomers (M), dimers (D) and higher-order oligomers $(\mathrm{H}-\mathrm{O})$.

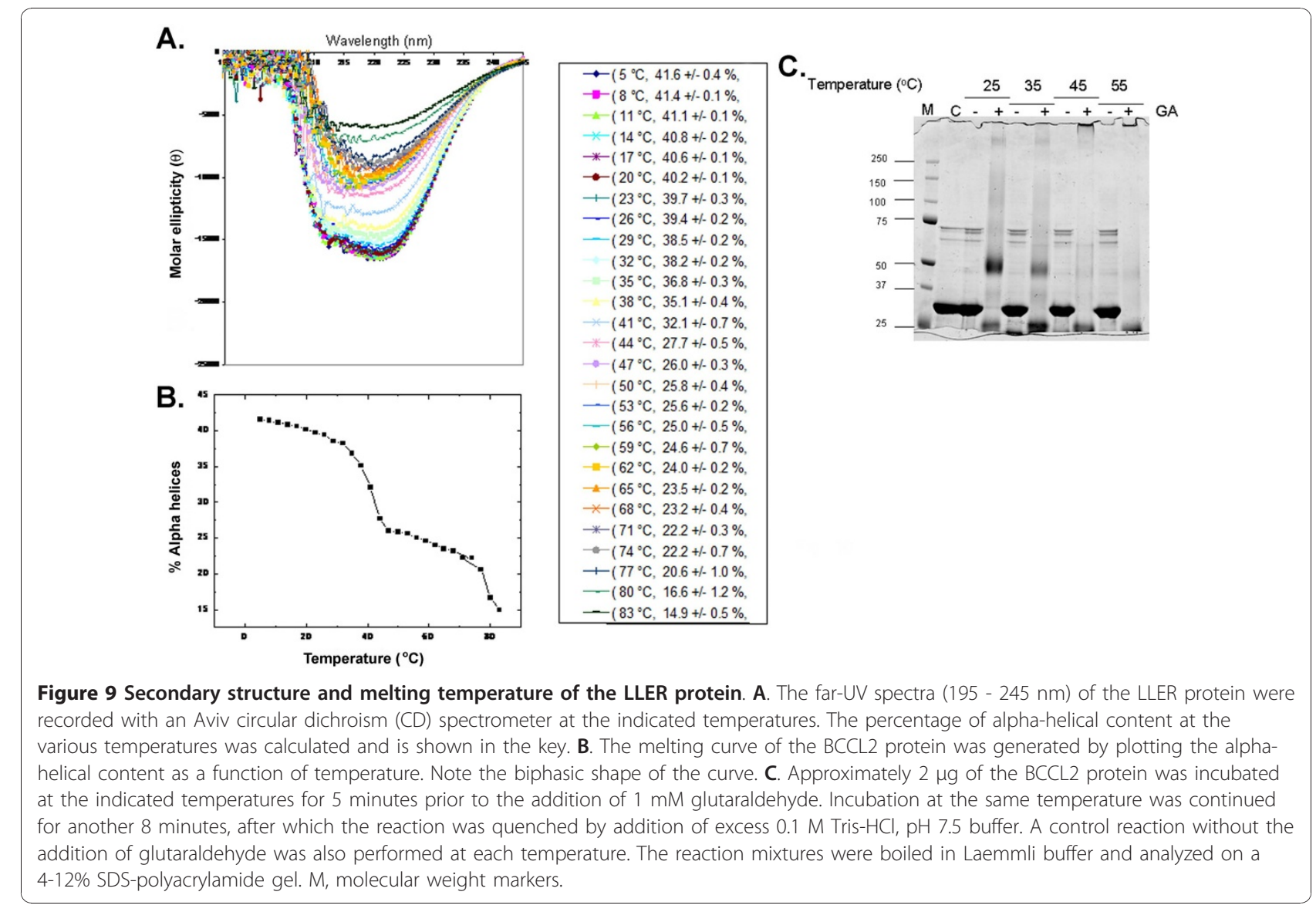




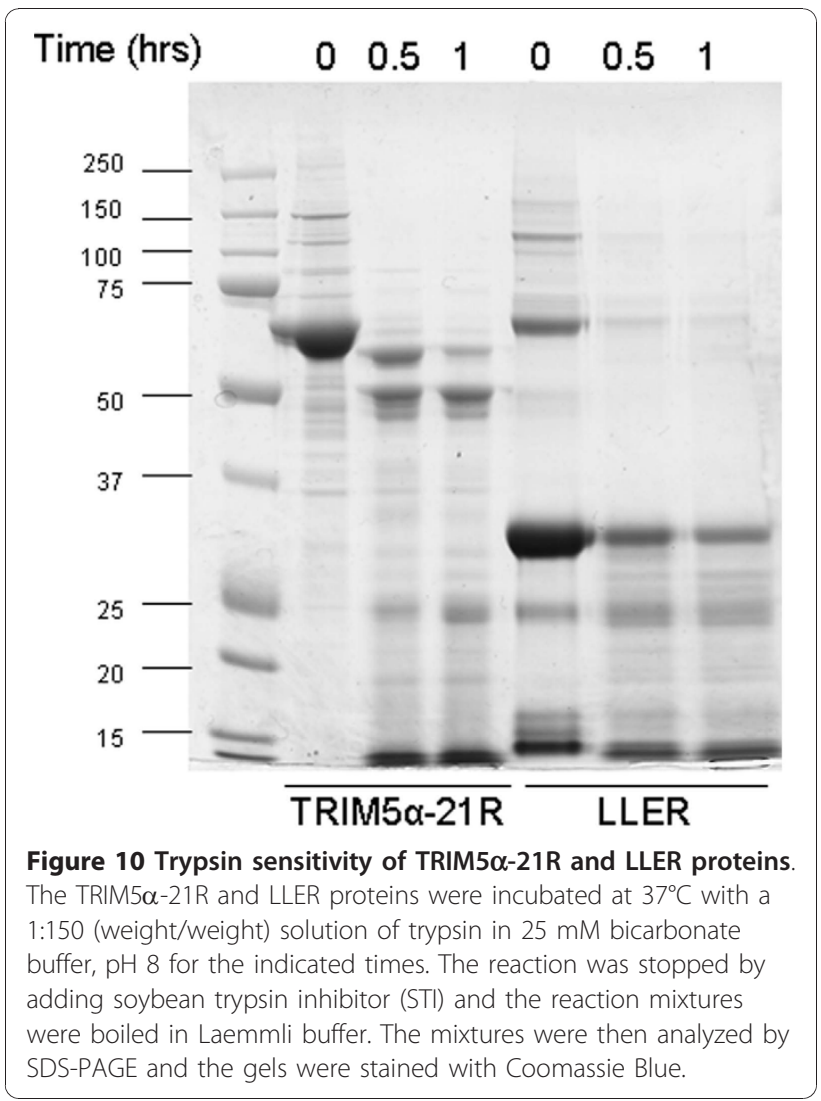

Most of the shapes on the grid were round or ovoid, although occasional filaments were observed (Figure 11A). Single-particle imaging by cryoelectron microscopy was performed on the peak 1 and peak 2 gelfiltration fractions of the LLER protein. The LLER proteins from peak 1 formed C-shaped structures roughly 120-130 A wide, with an appendage asymmetrically placed to one side of the arc (Figure 11B). The LLER proteins in peak 2 consisted of spherical structures approximately 105-115 $\AA$ in diameter (Figure 11C, panel 1 ). The addition of antibodies directed against the Nterminal $\mathrm{His}_{6}$ tag allowed visualization of complexes of the LLER protein with one antibody molecule (Figure $11 \mathrm{C}$, panel 3) or with two antibody molecules (Figure $11 \mathrm{C}$, panel 4). These results indicate that these structures represented LLER multimers that were at least dimeric.

\section{Discussion}

Previous studies of the TRIM5 $\alpha-21 \mathrm{R}$ protein suggested that TRIM5 $\alpha$ preferentially forms dimers $[28,29]$. One of the major protease-resistant fragments of TRIM5 $\alpha$ $21 \mathrm{R}$ consisted of the B-box 2 and coiled-coil domains, as well as the adjacent linker 2 (L2) region [28]. Here, we produced this protease-resistant fragment (BCCL2) of rhesus monkey TRIM5 $\alpha$ and verified that it is relatively resistant to trypsin digestion compared with the TRIM $5 \alpha-21 R$ protein. Protease resistance often is associated with the absence of conformationally flexible surface loops on a protein and thus might indicate a propensity to crystallize [70,71]. Although the polydispersity of the purified BCCL2 protein is high, an unfavorable predictor of crystallizability [71,72], additional modifications of the protein, optimization of solvent conditions or the inclusion of appropriate ligands may facilitate crystallization.

Our results demonstrate that, in the absence of other eukaryotic proteins, the BCCL2 protein forms dimers. Thus, the B-box 2 and coiled-coil domains, as well as the adjacent L2 region, are sufficient for TRIM5 dimerization. Neither of the terminal domains (i.e., RING or B30.2(SPRY)) is required for efficient dimerization. The estimates of the secondary structure content of the BCCL2 protein at different temperatures are consistent with predictions that the coiled-coil domain of TRIM proteins is mostly alpha helical [65-67]. Exposure to $45^{\circ} \mathrm{C}$ resulted in a dissociation of the dimer and a decrease in the helicity of the protein. The integrity of the dimer interface and that of a subset of the alphahelical structures on TRIM5 may be interconnected. Such a situation might be expected if dimeric contacts exist along the exposed surface of the alpha helices of each subunit of the dimer.

The BCCL2 dimers formed higher-order structures. Recently it has been reported that the full-length rhesus monkey TRIM5 $\alpha$ protein forms dimers, trimers, hexamers and multimers of higher complexity in mammalian cells; the hexameric form in particular appeared to be the most abundant multimer [30]. TRIM5 $\alpha$ multimerization does not involve disulfide bonds and is not affected by infection with restriction-sensitive viruses [30]. The formation of the functional TRIM5 higherorder oligomers depends upon specific B-box 2 amino acid residues $[16,26]$, several of which were altered in the BCCL2 protein without apparent disruption of the higher-order oligomerization. However, multiple changes in the B-box 2 surface did decrease the amount of large BCCL2 aggregates. This allowed more homogeneous preparations of a BCCL2 variant, LLER, to be analyzed by electron microscopy. Single-particle analysis revealed that the lower-molecular-weight form of LLER consisted of approximately 10-nm spheres. These LLER forms likely represent dimers; consistent with this, many examples of complexes consisting of two anti-His ${ }_{6}$ antibodies bound to a single LLER sphere were evident. The TRIM5 coiled coil, which is approximately 100 amino acid residues in length, could not be accommodated in these $10-\mathrm{nm}$ spheres as a linear, rod-like structure; the existence of insertions at specific locations in the coiled coil regions of TRIM5 variants is consistent with the 


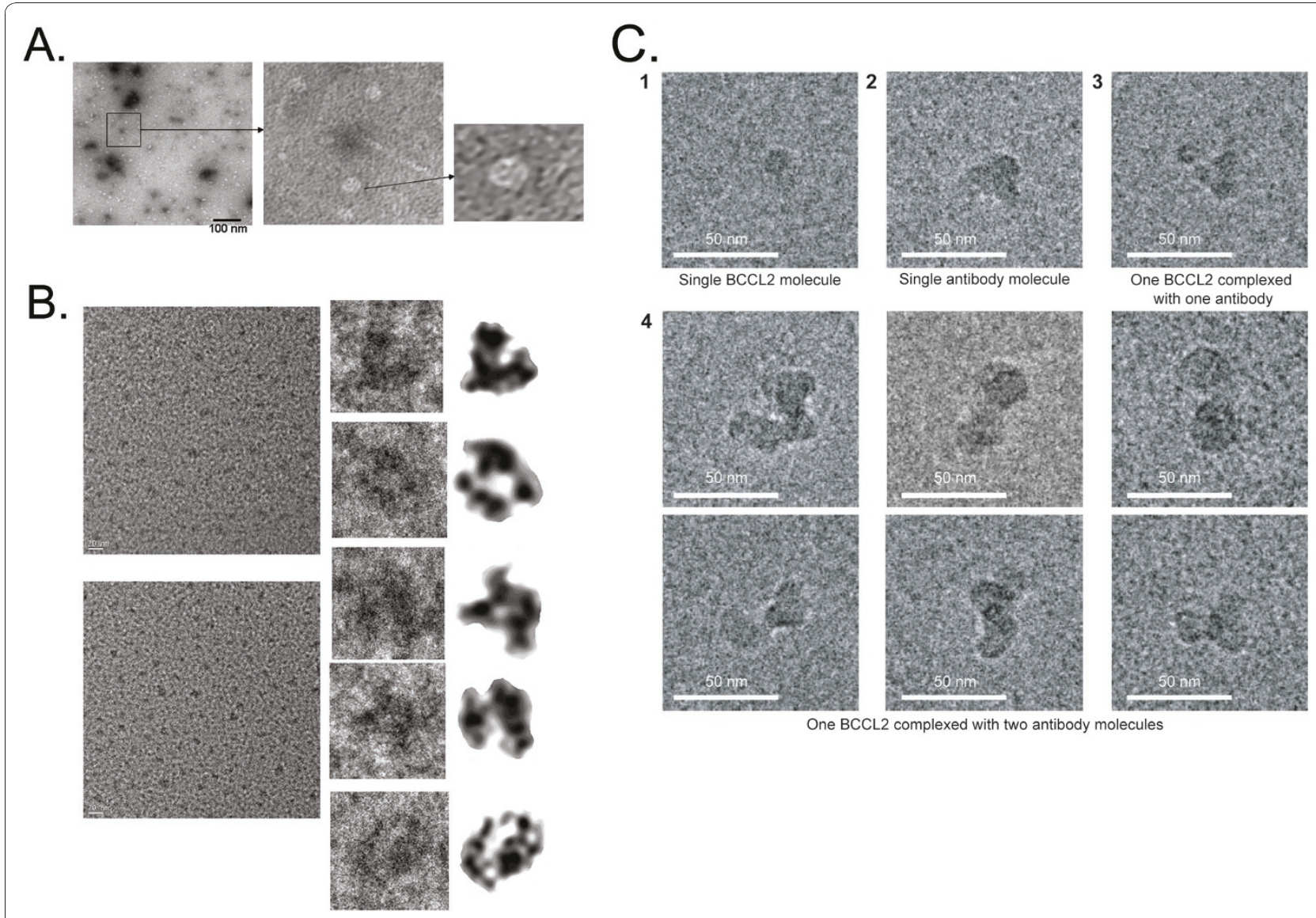

Figure 11 Electron microscopy of the LLER protein. A. The BCCL2 LLER protein purified by nickel-affinity, anion-exchange, and gel-filtration chromatography was applied to glow-discharged carbon grids. After staining with $1 \%$ uranyl formate, the grids were examined with a Tecnai G2 Spirit BioTWIN electron microscope (FEI Company) at $100 \mathrm{kV}$. B. The cryoelectron microscopic images of the LLER protein were taken at a magnification of 150,000 $\times$ and at a defocus of 3 5 $\mu \mathrm{m}$ with a Tecnai F20 field-emission gun electron microscope operating at $200 \mathrm{kV}$. The proteins that were purified as described above were embedded in a thin ice film on a Quantifoil grid, using an FEl Vitrobot, a robot that swiftly plunges the protein-loaded grid into liquid ethane. The images were low-pass filtered with background noises removed (right column). The bars in the left-hand images are $20 \mathrm{~nm}$. C. The Peak 2 fraction of the LLER protein was incubated with an anti-His 6 antibody and imaged by singleparticle cryoelectron microscopy, as described above. Representative images of the LLER protein alone (panel 1), the antibody alone (panel 2), and the LLER protein complexed with one or two antibody molecules (panels 3 and 4, respectively) are shown.

possibility that the coiled coil bends or folds back upon itself. The higher molecular weight LLER complexes formed C-shaped structures, with an appendage protruding from the convex side of the arc. The size of these structures is larger than that expected for a dimer, and possibly represents a pentamer or hexamer. We do not know if these higher-order structures are biologically relevant; it may be that the TRIM $5 \alpha$ domains (RING and B30.2(SPRY)) not included in the BCCL2 construct influence higher-order self-association either quantitatively or qualitatively. Future work will explore these issues.

\section{Conclusions}

The central core of TRIM5 $\alpha$, consisting of the B-box 2, coiled coil and L2 linker region, forms dimers that are largely alpha helical. The melting of the alpha-helical structure of this TRIM5 $\alpha$ core was biphasic, with one transition at $42^{\circ} \mathrm{C}$ associated with a loss of dimerization, and a second transition at $80^{\circ} \mathrm{C}$.

\section{Abbreviations}

TRIM: tripartite motif; HIV: human immunodeficiency virus; SIV: simian immunodeficiency virus; SEC: size-exclusion chromatography; BCCL2: B-box 2 - coiled coil - linker 2; HRP: horseradish peroxidase; CD: circular dichroism; MALDI-TOF: matrix-assisted laser desorption ionization-time of flight; PBS: phosphate-buffered saline.

\section{Acknowledgements}

We thank Ms. Yvette McLaughlin and Elizabeth Carpelan for manuscript preparation. We thank Ewa Folta-Stogniew for SEC-LS in the HHMI Biopolymer Facility and W. M. Keck Foundation Biotechnology Resource Laboratory at Yale University, and Walter Stafford, Boston Biomedical Research Institute, Watertown, MA for advice and assistance. This work was made possible by grants from the National Institutes of Health (Al 063987, Al 
076094 and a Center for AIDS Research Award Al 06354) and the International AIDS Vaccine Initiative, and a gift from the late William F. McCarty-Cooper.

\section{Author details}

${ }^{1}$ Department of Cancer Immunology and AIDS, Dana-Farber Cancer Institute, Harvard Medical School, Boston, MA, USA 02115. ²Department of Pathology, Division of AIDS, Harvard Medical School, Boston, MA, USA 02115. ${ }^{3}$ Department of Pediatric Oncology, Dana-Farber Cancer Institute, Harvard Medical School, Boston, MA, USA 02115. ${ }^{4}$ Department of Immunology and Infectious Disease, Harvard School of Public Health, Boston, MA, USA 02115.

\section{Authors' contributions}

AK, YM, GB, LW and JS designed the experiments. AK, YM and GB performed the experiments. All of the authors participated in the interpretation of the data. AK, LW, and JS wrote the manuscript. All authors read and approved the final manuscript.

Received: 21 September 2010 Accepted: 4 January 2011 Published: 4 January 2011

\section{References}

1. Shibata R, Sakai H, Kawamura M, Tokunaga K, Adachi A: Early replication block of human immunodeficiency virus type 1 in monkey cells. J Gen Virol 1995, 76(Pt 11):2723-2730.

2. Himathongkham S, Luciw PA: Restriction of HIV-1 (subtype B) replication at the entry step in rhesus macaque cells. Virology 1996, 219(2):485-488.

3. Hofmann W, Schubert D, LaBonte J, Munson L, Gibson S, Scammell J, Ferrigno P, Sodroski J: Species-specific, postentry barriers to primate immunodeficiency virus infection. J Virol 1999, 73(12):10020-10028.

4. Cowan S, Hatziioannou T, Cunningham T, Muesing MA, Gottlinger HG, Bieniasz PD: Cellular inhibitors with Fv1-like activity restrict human and simian immunodeficiency virus tropism. Proc Natl Acad Sci USA 2002, 99(18):11914-11919.

5. Song B, Javanbakht $H$, Perron $M$, Park DH, Stremlau M, Sodroski J: Retrovirus restriction by TRIM5alpha variants from Old World and New World primates. J Virol 2005, 79(7):3930-3937.

6. Nakayama EE, Shioda T: Anti-retroviral activity of TRIM5alpha. Rev Med Virol 2010, 20(2):77-92

7. Stremlau M, Owens CM, Perron MJ, Kiessling M, Autissier P, Sodroski J: The cytoplasmic body component TRIM5alpha restricts HIV-1 infection in Old World monkeys. Nature 2004, 427(6977):848-853.

8. Hatziioannou T, Perez-Caballero D, Yang A, Cowan S, Bieniasz PD: Retrovirus resistance factors Ref1 and Lv1 are species-specific variants of TRIM5alpha. Proc Natl Acad Sci USA 2004, 101(29):10774-10779.

9. Keckesova Z, Ylinen LM, Towers GJ: The human and African green monkey TRIM5alpha genes encode Ref1 and Lv1 retroviral restriction factor activities. Proc Natl Acad Sci USA 2004, 101(29):10780-10785.

10. Kratovac Z, Virgen CA, Bibollet-Ruche F, Hahn BH, Bieniasz PD, Hatziioannou T: Primate lentivirus capsid sensitivity to TRIM5 proteins. $J$ Virol 2008, 82(13):6772-6777.

11. Yap MW, Nisole S, Lynch C, Stoye JP: Trim5alpha protein restricts both HIV-1 and murine leukemia virus. Proc Natl Acad Sci USA 2004, 101(29):10786-10791.

12. Ylinen LM, Keckesova Z, Wilson SJ, Ranasinghe S, Towers GJ: Differential restriction of human immunodeficiency virus type 2 and simian immunodeficiency virus SIVmac by TRIM5alpha alleles. J Virol 2005, 79(18):11580-11587.

13. Diaz-Griffero F, Kar A, Lee M, Stremlau M, Poeschla E, Sodroski J: Comparative requirements for the restriction of retrovirus infection by TRIM5alpha and TRIMCyp. Virology 2007, 369(2):400-410.

14. Diaz-Griffero F, Kar A, Perron M, Xiang SH, Javanbakht H, Li X, Sodroski J: Modulation of retroviral restriction and proteasome inhibitor-resistant turnover by changes in the TRIM5alpha B-box 2 domain. J Virol 2007, 81(19):10362-10378.

15. Diaz-Griffero F, Perron M, McGee-Estrada K, Hanna R, Maillard PV, Trono D, Sodroski J: A human TRIM5alpha B30.2/SPRY domain mutant gains the ability to restrict and prematurely uncoat B-tropic murine leukemia virus. Virology 2008, 378(2):233-242.

16. Diaz-Griffero F, Qin XR, Hayashi F, Kigawa T, Finzi A, Sarnak Z, Lienlaf M, Yokoyama S, Sodroski J: A B-box 2 surface patch important for
TRIM5alpha self-association, capsid binding avidity, and retrovirus restriction. J Virol 2009, 83(20):10737-10751.

17. Perron MJ, Stremlau M, Lee M, Javanbakht H, Song B, Sodroski J: The human TRIM5alpha restriction factor mediates accelerated uncoating of the N-tropic murine leukemia virus capsid. J Virol 2007, 81(5):2138-2148.

18. Sebastian S, Luban J: TRIM5alpha selectively binds a restriction-sensitive retroviral capsid. Retrovirology 2005, 2:40.

19. Stremlau M, Perron M, Lee M, Li Y, Song B, Javanbakht H, Diaz-Griffero F, Anderson DJ, Sundquist WI, Sodroski J: Specific recognition and accelerated uncoating of retroviral capsids by the TRIM5alpha restriction factor. Proc Natl Acad Sci USA 2006, 103(14):5514-5519.

20. Meroni G, Diez-Roux G: TRIM/RBCC, a novel class of 'single protein RING finger' E3 ubiquitin ligases. Bioessays 2005, 27(11):1147-1157.

21. Reymond A, Meroni G, Fantozzi A, Merla G, Cairo S, Luzi L, Riganelli D, Zanaria $E$, Messali $S$, Cainarca $S$, et al: The tripartite motif family identifies cell compartments. EMBO J 2001, 20(9):2140-2151.

22. Javanbakht H, Diaz-Griffero F, Stremlau M, Si Z, Sodroski J: The contribution of RING and B-box 2 domains to retroviral restriction mediated by monkey TRIM5alpha. J Biol Chem 2005, 280(29):26933-26940.

23. Perez-Caballero D, Hatziioannou T, Yang A, Cowan S, Bieniasz PD: Human tripartite motif 5alpha domains responsible for retrovirus restriction activity and specificity. J Virol 2005, 79(14):8969-8978.

24. Maegawa H, Miyamoto T, Sakuragi J, Shioda T, Nakayama EE: Contribution of RING domain to retrovirus restriction by TRIM5alpha depends on combination of host and virus. Virology 2010, 399:212-220.

25. Li X, Song B, Xiang SH, Sodroski J: Functional interplay between the B-box 2 and the B30.2(SPRY) domains of TRIM5alpha. Virology 2007, 366(2):234-244.

26. Li X, Sodroski J: The TRIM5alpha B-box 2 domain promotes cooperative binding to the retroviral capsid by mediating higher-order selfassociation. J Virol 2008, 82(23):11495-11502.

27. Javanbakht H, Yuan W, Yeung DF, Song B, Diaz-Griffero F, Li Y, Li X, Stremlau M, Sodroski J: Characterization of TRIM5alpha trimerization and its contribution to human immunodeficiency virus capsid binding. Virology 2006, 353(1):234-246.

28. Kar AK, Diaz-Griffero F, Li Y, Li X, Sodroski J: Biochemical and biophysical characterization of a chimeric TRIM21-TRIM5alpha protein. J Virol 2008, 82(23):11669-11681.

29. Langelier CR, Sandrin V, Eckert DM, Christensen DE, Chandrasekaran V, Alam SL, Aiken C, Olsen JC, Kar AK, Sodroski JG, et al: Biochemical characterization of a recombinant TRIM5alpha protein that restricts human immunodeficiency virus type 1 replication. J Virol 2008, 82(23):11682-11694.

30. Nepveu-Traversy ME, Berube J, Berthoux L: TRIM5alpha and TRIMCyp form apparent hexamers and their multimeric state is not affected by exposure to restriction-sensitive viruses or by treatment with pharmacological inhibitors. Retrovirology 2009, 6:100.

31. Johnson WE, Sawyer SL: Molecular evolution of the antiretroviral TRIM5 gene. Immunogenetics 2009, 61(3):163-176.

32. Soares EA, Menezes AN, Schrago CG, Moreira MA, Bonvicino CR, Soares MA, Seuanez HN: Evolution of TRIM5alpha B30.2 (SPRY) domain in New World primates. Infect Genet Evol 2010, 10:246-253.

33. Sawyer SL, Wu LI, Emerman M, Malik HS: Positive selection of primate TRIM5alpha identifies a critical species-specific retroviral restriction domain. Proc Natl Acad Sci USA 2005, 102(8):2832-2837.

34. Song B, Gold B, O'Huigin C, Javanbakht H, Li X, Stremlau M, Winkler C, Dean M, Sodroski J: The B30.2(SPRY) domain of the retroviral restriction factor TRIM5alpha exhibits lineage-specific length and sequence variation in primates. J Virol 2005, 79(10):6111-6121.

35. Johnson WE, Sawyer SL: Molecular evolution of the antiretroviral TRIM5 gene. Immunogenetics 2009, 61(3):163-176.

36. Sawyer SL, Emerman M, Malik HS: Discordant evolution of the adjacent antiretroviral genes TRIM22 and TRIM5 in mammals. PLoS Pathog 2007, 3 e197.

37. Stremlau M, Perron M, Welikala S, Sodroski J: Species-specific variation in the B30.2(SPRY) domain of TRIM5alpha determines the potency of human immunodeficiency virus restriction. J Virol 2005, 79(5):3139-3145.

38. Kono K, Bozek K, Domingues FS, Shioda T, Nakayama EE: Impact of a single amino acid in the variable region 2 of the Old World monkey TRIM5alpha SPRY (B30.2) domain on anti-human immunodeficiency virus type 2 activity. Virology 2009, 388(1):160-168. 
39. Perron MJ, Stremlau M, Sodroski J: Two surface-exposed elements of the B30.2/SPRY domain as potency determinants of $\mathrm{N}$-tropic murine leukemia virus restriction by human TRIM5alpha. J Virol 2006 80(11):5631-5636.

40. Ohkura S, Yap MW, Sheldon T, Stoye JP: All three variable regions of the TRIM5alpha B30.2 domain can contribute to the specificity of retrovirus restriction. J Virol 2006, 80(17):8554-8565.

41. Nakayama EE, Miyoshi $H$, Nagai $Y$, Shioda $T$ : A specific region of 37 amino acid residues in the SPRY (B30.2) domain of African green monkey TRIM5alpha determines species-specific restriction of simian immunodeficiency virus SIVmac infection. J Virol 2005, 79(14):8870-8877.

42. Li Y, Li X, Stremlau M, Lee M, Sodroski J: Removal of arginine 332 allows human TRIM5alpha to bind human immunodeficiency virus capsids and to restrict infection. J Virol 2006, 80(14):6738-6744.

43. Kaiser SM, Malik HS, Emerman M: Restriction of an extinct retrovirus by the human TRIM5alpha antiviral protein. Science 2007, 316:1756-1758.

44. Yap MW, Nisole S, Stoye JP: A single amino acid change in the SPRY domain of human Trim5alpha leads to HIV-1 restriction. Curr Biol 2005, 15(1):73-78

45. Maillard PV, Reymond S, Serhan F, Turelli P, Trono D: Interfering residues narrow the spectrum of MLV restriction by human TRIM5a. PLOS Pathog 2007, 3:e200.

46. Lim SY, Rogers T, Chan T, Whitney JB, Kim J, Sodroski J, Letvin N: TRIM5alpha modulates immunodeficiency virus control in rhesus monkeys. PLoS Pathog 2010, 6(1):e1000738.

47. Maillard PV, Ecco G, Ortiz M, Trono D: The specificity of TRIM5 alphamediated restriction is influenced by its coiled-coil domain. J Virol 2010, 84:5790-5801.

48. Grignani F, Fagioli M, Alcalay M, Longo L, Pandolfi PP, Donti E, Biondi A, Lo Coco F, Pelicci PG: Acute promyelocytic leukemia: from genetics to treatment. Blood 1994, 83:10-25.

49. The French FMF Consortium: A candidate gene for familial Mediterranean fever. Nature Genet 1997, 17:25-31.

50. The International FMF Consortium: Ancient missense mutations in a new member of the RoRet gene family are likely to cause familial Mediterranean fever. Cell 1997, 90:797-807.

51. Quaderi NA, Schweiger S, Gaudenz K, Franco B, Rugarli EL, Berger W, Feldman GJ, et al: Opitz G/BBB syndrome, a defect of midline development is due to mutations in a new RING finger gene on Xp22. Nature Genet 1997, 17:285-291.

52. Ben-Chetrit E, Chan EK, Sullivan KF, Tan EM: A 52-kD protein is a novel component of the SS-A/Ro antigenic particle. J Exp Med 1988, 167:1560-1571.

53. Moutsopoulos HM, Skopouli FN, Sarras AK, Tsampoulas C, Mavridis AK, Constantopoulos SH, Maddison PJ: Anti-Ro(SSA) positive rheumatoid arthritis (RA): a clinicoserological group of patients with high incidence of D-penicillamine side effects. Ann Rheum Dis 1985, 44:215-219.

54. Avela K, Lipsanen-Nyman M, Idanheimo N, Seemanova E, Rosengren S, Makela TP, Perheentupa J, Chapelle A, Lehesjoki AE: Gene encoding a new RING-B-box-coiled-coil protein is mutated in mulibrey nanism. Nature Genet 2000, 25:298-301.

55. Abe H, Miyamoto K, Tochio N, Koshiba S, Kigawa T, Yokoyama S: Solution structure of the zinc finger, C3HC4 type (RING finger) domain of tripartite motif-containing protein 5. RCSB Protein Data Bank, Piscataway, NJ. vol. RIKEN Structural Genomics/Proteomics Initiative (RSGI), Accession number 2ecv RIKEN Structural Genomics/Proteomics Initiative (RSGI); 2008.

56. Tao H, Simmons BN, Singireddy S, Jakkidi M, Short KM, Cox TC, Massiah MA: Structure of the MID1 tandem B-boxes reveals an interaction reminiscent of intermolecular ring heterodimers. Biochemistry 2008, 47(8):2450-2457.

57. Mrosek M, Meier S, Ucurum-Fotiadis Z, von Castelmur E, Hedbom E, Lustig A, Grzesiek S, Labeit D, Labeit S, Mayans O: Structural analysis of BBox 2 from MuRF1: identification of a novel self-association pattern in a RING-like fold. Biochemistry 2008, 47(40):10722-10730.

58. Massiah MA, Matts JA, Short KM, Simmons BN, Singireddy S, Yi Z, Cox TC: Solution structure of the MID1 B-box2 $\mathrm{CHC}(\mathrm{D} / \mathrm{C}) \mathrm{C}(2) \mathrm{H}(2)$ zinc-binding domain: insights into an evolutionarily conserved RING fold. J Mol Biol 2007, 369(1):1-10.

59. Massiah MA, Simmons BN, Short KM, Cox TC: Solution structure of the RBCC/TRIM B-box1 domain of human MID1: B-box with a RING. J Mol Biol 2006, 358(2):532-545
60. Masters SL, Yao S, Willson TA, Zhang JG, Palmer KR, Smith BJ, Babon JJ, Nicola NA, Norton RS, Nicholson SE: The SPRY domain of SSB-2 adopts a novel fold that presents conserved Par-4-binding residues. Nat Struct $\mathrm{Mol}$ Biol 2006, 13(1):77-84.

61. Woo JS, Suh HY, Park SY, Oh BH: Structural basis for protein recognition by B30.2/SPRY domains. Mol Cell 2006, 24(6):967-976.

62. Grutter C, Briand C, Capitani G, Mittl PR, Papin S, Tschopp J, Grutter MG: Structure of the PRYSPRY-domain: implications for autoinflammatory diseases. FEBS Lett 2006, 580(1):99-106.

63. James LC, Keeble AH, Khan Z, Rhodes DA, Trowsdale J: Structural basis for PRYSPRY-mediated tripartite motif (TRIM) protein function. Proc Natl Acad Sci USA 2007, 104(15):6200-6205.

64. Kuang Z, Yao S, Xu Y, Lewis RS, Low A, Masters SL, Willson TA, Kolesnik TB, Nicholson SE, Garrett TJ, et al: SPRY domain-containing SOCS box protein 2: crystal structure and residues critical for protein binding. J Mol Biol 2009, 386(3):662-674

65. Lupas A, Van Dyke M, Stock J: Predicting coiled coils from protein sequences. Science 1991, 252:1162-1164.

66. Parry DAD: Coiled-coils in alpha-helix-containing proteins: analysis of the residue types within the heptad repeat and the use of these data in the prediction of coiled coils in other proteins. Biosci Rep 1981, 2:1017-1024.

67. Berger B, Wilson DB, Wolf E, Tonchev T, Milla M, Kim PS: Predicting coiled coils by use of pairwise residue correlations. Proc Natl Acad Sci USA 1995, 92:8259-8263.

68. Mische CC, Javanbakht H, Song B, Diaz-Griffero F, Stremlau M, Strack B, Si Z, Sodroski J: Retroviral restriction factor TRIM5alpha is a trimer. J Virol 2005, 79(22):14446-14450.

69. Whitmore L, Wallace BA: Protein secondary structure analyses from circular dichroism spectroscopy: methods and reference databases. Biopolymers 2008, 89:392-400

70. Gao X, Bain K, Bonanno JB, Buchanan M, Henderson D, Morimer D, Marsch C, Reynes JA, Sauder JM, Schwinn K, Thai C, Burley SK: Highthroughput limited proteolysis/mass spectrometry for protein domain elucidation. J Struct Funct Genomics 2005, 6:129-134.

71. D'Arcy A: Crystallizing proteins: a rational approach? Acta Cryst 1994 D50:469-471.

72. Ferre-D'Amare A, Burley S: Dynamic light scattering in evaluating crystallizability of macromolecules. Methods in Enzymol 1997, 276:157-166.

doi:10.1186/1471-2091-12-1

Cite this article as: Kar et al: Characterization of a core fragment of the rhesus monkey TRIM5 $\alpha$ protein. BMC Biochemistry 2011 12:1.

\section{Submit your next manuscript to BioMed Central and take full advantage of:}

- Convenient online submission

- Thorough peer review

- No space constraints or color figure charges

- Immediate publication on acceptance

- Inclusion in PubMed, CAS, Scopus and Google Scholar

- Research which is freely available for redistribution

Submit your manuscript at www.biomedcentral.com/submit
C Biomed Central 